\title{
CENTRAL OBESITY ASSOCIATED WITH CHARACTERISTICS OF VASOMOTOR SYMPTOMS IN MENOPAUS WOMEN
}

\author{
Yuniar Setyawati ${ }^{1}$, Ashon Sa'adi ${ }^{2}$, Tiyas Kusumaningrum ${ }^{3}$ \\ 1Midwifery program, Faculty of Medicine, Universitas Airlangga, Surabaya,60131, Indonesia \\ 2 Obstetric and Gynecologic Department, faculty of Medicine, Universitas Airlangga, Surabaya,60131 Indonesia \\ 3Maternity and Pediatric Department, Faculty of Nursing, Universitas Airlangga, Surabaya, 60115, Indonesia
}

\section{INFORMASI ARTIKEL:}

\section{Riwayat Artikel:}

Tanggal diterima: Maret 2021

Tanggal di revisi: Maret 2021

Tanggal di Publikasi: April 2021

Key Word: Menopause, Central Obesity Vasomotor symptoms

\section{A B S T R A C T}

Background: Vasomotor complaints are common on postmenopausal women. Most women feel these complaints within 2 years after entering menopause; some of them will even feel up to a decade. In addition to vasomotor complaints, the incidence of central obesity also increases in menopause. The poor adipocyte system in central obesity that affects the central nervous system, body temperature and excessive sympathetic nerve activity have been suspected to be a cause of vasomotor syndrome at menopause. The purpose of this study was to analyze the relationship between central obesity and the characteristic of vasomotor symptoms in postmenopausal women. Method: this observational analytic study used a cross sectional design. The number of samples were 86 women aged 45-55 years who had been in postmenopausal period. Sampling technique was consecutive sampling. The independent variable was central obesity while the dependent variable was vasomotor symptoms. The data was taken using modified MENQOL questionnaire and direct measurements waist circumference to determine central obesity in the respondents. Data was tested using contingency coefficient test with $\alpha 0.05$. Results: There were $59.3 \%$ respondents who experienced central obesity. More than eighty percent respondents with central obesity also experienced vasomotor symptoms which were considered disturbing. There was a significant relation between central obesity and the characteristic of vasomotor symptoms in postmenopausal women $(\mathrm{p}=0.00 ; \mathrm{r}=0.513)$. Conclusion: The presence of central obesity leads to disturbing vasomotor symptoms in postmenopausal women. 


\section{INTRODUCTION}

In Indonesia, the incidence of central obesity at the age of $>18$ years has increased every year. In 2018, there were $31 \%$ incidences of central obesity, while in East Java there were $30 \%$ incidences of central obesity from the total population (RISKESDAS, 2019). This study was conducted by Sofa at one of the elderly posyandu in Surabaya in 2018. Of 81 respondents, $17.3 \%$ had central obesity (Sofa, 2018). High central obesity rates in menopause are caused by the presence of fat that is redistributed during or after menopause. The distribution of body fat to the abdomen causes an increase in abdominal circumference of 4 cm every 9 years in adult women (Tuomikoski and Savolainen-Peltonen, 2017). Central obesity in menopause is also caused by several factors, one of which is hormonal factors, i.e., decreasing estrogen levels which is the result of increased distribution of fat to the center of the body. The female hormone, estrogen, is responsible for the accumulation of fat in the subcutaneous tissue, especially in the gluteal and femoral areas. The decrease in sex hormone binding globulin (SHBG) can cause androgen production to increase. Androgen hormones can cause the accumulation of abdominal fat so that high androgen hormones and decreased estrogen hormones can cause an increase in central obesity in postmenopausal women (Kozakowski et al, 2017). According to several studies, central obesity in menopause can increase the risk of metabolic syndrome, type 2 diabetes, hypertension, atherosclerosis, cardiovascular disorders and dyslipidemia (Prastiwi, 2018).

The study conducted in 2016 on 16,000 women aged 45-55 years revealed that a high waist circumference can exacerbate vasomotor symptoms (Karvonen-Gutierrez and Kim, 2016). Poor adipokine in central obesity can affect the central nervous system, sympathetic nervous activity, and body temperature, so it is suspected to be the cause of the aggravation of vasomotor symptoms. In Indonesia, there are no studies related to central obesity and its

"Korespondensi: E-mail : yuniarsetya2@gmail.com relationship to vasomotor symptoms in postmenopausal women. Therefore, this study was conducted to analyze the relationship between central obesity and vasomotor symptoms, which are common symptoms felt by postmenopausal women. Early recognition of the presence of central obesity in menopause can help prevent and overcome postmenopausal problems, as well as longterm effects in the form of worsening vasomotor symptoms, as well as the emergence of various degenerative diseases that may be caused.

\section{METHOD}

This observational analytic study used a cross sectional design. The population was the entire community of Sumberwaru Sub-village aged 45-55 years who had been at postmenopausal period. The sampling technique used consecutive sampling technique. The sample size was 86 respondents. The independent variable was central obesity. Determination of central obesity used waist circumference. Respondent's waist circumference $>80 \mathrm{~cm}$ was said to have central obesity. The dependent variable was the level of characteristic vasomotor symptoms. This variable was measured using the MENQOL questionnaire which was modified into 3 questions regarding vasomotor symptoms such as hot flushes, night sweats and easy sweating despite not doing strenuous activities. Characteristics of vasomotor symptoms were assessed into 2 categories, i.e., disturbed and undisturbed. The assessment was based on the total number of scores filled out by respondents in the questionnaire.

This respondents had been given explanations and informed consent. The subsequent action was measuring the respondents' waist circumference respondent and gaving a questionnaire sheet to be filled out. After the data was collected, it was processed by editing, coding, scoring, processing and cleaning. The data that had been collected was processed and analyzed using a contingency coefficient test with a significance limit of 5\% (0.05) with the use of the SPSS program. 


\section{RESULT AND DISCUSSION}

Respondents with central obesity had the highest prevalence of impaired vasomotor symptoms $(80.4 \%)$. The prevalence of central obesity in this study was 51 people from 86 respondents, with an average waist circumference of $82.04 \mathrm{~cm}$ and an average BMI of $21.6 \mathrm{~kg} / \mathrm{m} 2$.

Table 1. Relationship between central obesity and characteristics of vasomotor symptoms in postmenopausal women

\begin{tabular}{|c|c|c|c|c|c|c|c|}
\hline & & \multicolumn{4}{|c|}{ Vasomotor Symptom } & \multicolumn{2}{|c|}{ Total } \\
\hline & & \multicolumn{2}{|c|}{ Disturbed } & \multicolumn{2}{|c|}{ Undisturbed } & \multirow[b]{2}{*}{$\mathbf{n}$} & \multirow[b]{2}{*}{$\%$} \\
\hline & & f & $\%$ & $\mathbf{n}$ & $\%$ & & \\
\hline \multirow[t]{2}{*}{$\begin{array}{l}\text { Central } \\
\text { obesity }\end{array}$} & $\begin{array}{l}\text { Central } \\
\text { obesity }\end{array}$ & 41 & $\begin{array}{c}80 . \\
4\end{array}$ & 10 & 19.6 & 51 & 100 \\
\hline & $\begin{array}{l}\text { Non- } \\
\text { Central } \\
\text { obesity }\end{array}$ & 7 & $\begin{array}{c}20 . \\
0\end{array}$ & 28 & 80.0 & 35 & 100 \\
\hline Total & & 48 & $\begin{array}{c}55 . \\
8\end{array}$ & 38 & 44.2 & 86 & 100 \\
\hline & & $\overline{<\alpha=0}$ & $\overline{0 ; \mathrm{C}}$ & 0.51 & & & \\
\hline
\end{tabular}

Central obesity is an accumulation of visceral fat. The fat storage area in humans is divided into 2, i.e., subcutaneous fat and visceral fat. Subcutaneous fat is the fat that is spread all over the body and is located under the skin. Visceral fat is the fat that lies between the visceral organs such as, intestines, liver, heart, stomach, kidneys and so on (Clark, 2008).

Too much visceral fat causes increased levels of C-reactive protein and other clotting proteins that can lead to metabolic syndrome (high waist circumference causes increased glucose, high blood pressure and high density lipoprotein levels, HDL cholesterol and high triglyceride levels) (Dunford \& Doyle, 2007). Central obesity is also characterized by mild chronic inflammation of adipose tissue resulting in impaired regulation of adipokine secretion, endothelial dysfunction and metabolic dysregulation. Epidemiological and longitudinal studies have linked central obesity with vasomotor symptoms. This contradicts the traditional assumption that adipose fat protects against hot flushes by aromatizing androgens to estrogens (Tuomikoski and Savolainen-Peltonen, 2017).
The results of the contingency coefficients for both variables indicate that there is a significant relationship between central obesity and the characteristics of vasomotor symptoms in postmenopausal women. This is in accordance with a study conducted by Ghazanfarpour in 2013 using the MENQOL questionnaire that obese women had a significantly higher score in the physical symptoms domain, while women with android fat distribution patterns or dominant fat storage in the abdomen had significantly higher scores (Khotiyal and Monika, 2013). This study was also conducted in Ecuador on 325 postmenopausal women who were surveyed using the MENQOL questionnaire and screened for metabolic syndrome. This study concluded that women with central obesity have a greater risk of experiencing vasomotor symptoms (Chedraui et al., 2007). A similar study was conducted on 183 women in St. Vincent's Korea who were divided into 2 groups of respondents with central obesity and without central obesity. This study stated that vasomotor symptoms such as hot flushes, more night sweats, and easy sweating were found in the central obesity group (Lee Suk et al., 2011).

Another study was conducted by Ryu et al in 2016 on the relationship between vasomotor syndrome and metabolic syndrome in postmenopausal women aged 54 years. This study found that $58 \%$ of respondents experienced vasomotor syndrome (Ryu et al., 2016). An American study of 16,000 women aged 45-55 years stated that central obesity was significantly associated with postmenopausal symptoms such as hot flushes, night sweats, urinalysis, and joint aches and pains (Karvonen-Gutierrez and Kim, 2016).

A study with different results was conducted on 20 postmenopausal women in Turkey that there was no significant relationship between the severity of the perceived vasomotor symptoms and central obesity. This study also states that postmenopausal women who experience moderate to mild vasomotor syndrome are more common in postmenopausal women who do not have central obesity (Sayan \& Pekin, 2018). 
The increase in symptoms of vasomotor syndrome experienced by postmenopausal women is not only caused by the presence of central obesity or large waist circumference. Vasomotor symptoms is also significantly associated with younger age, shorter menopause, high BMI, poor lipid profile and education level. This is believed to affect the process of adaptation and self-acceptance to the changes that occur before and during menopause.

\section{CONCLUSION}

It can be concluded that there is a relationship between central obesity and the characteristics of vasomotor symptoms in postmenopausal women. The presence of central obesity causes vasomotor syndrome disorders in postmenopausal women. With this study, postmenopausal women are expected to prevent central obesity as early as possible by adjusting their diet, exercising regularly and having regular health check-ups.

\section{AKNOWLEDGEMENT}

Thank you to the head of Palrejo Village and the staff as well as the head of the Sumberwaru Sub-village who have given permission to conduct the research, the respondents and many parties who have helped during the process of this study.

\section{REFERENCE}

Avis, Nancy E. et al. 2015. "Duration of Postmenopausal Vasomotor Symptoms over the Menopause Transition." JAMA Internal Medicine. (23 Januari 2020)

Clark, David. 2008. Longevity : a few tips the free radical connection health, diet and fitness information. O Vassali : UK

Chedraui, P., Hidalgo, L., Chavez, D., Morocho, N., Alvarado, M., \& Huc, A. (2007). Quality of life among postmenopausal Ecuadorian women participating in a metabolic syndrome screening program. Maturitas. https://doi.org/10.1016/j.maturitas.2006.05.00 8
Dunford, Merie., Doyle, J. 2007. Nutrition for Sport and Exercise. Cencage Learning : Boston

Karvonen-Gutierrez, Carrie, and Catherine Kim. 2016. "Association of Mid-Life Changes in Body Size, Body Composition and Obesity Status with the Postmenopausal Transition." Healthcare 4(3): 42. (02 Februari 2020)

Kothiyal P, Monika S (2013). Post postmenopausal quality of life and associated factors-A Review. Journal of Scientific and Innovative Research, 2(4): 814- 823.

Kozakowski, Jaroslaw, Malgorzata GietkaCzernel, Dorota Leszczynska, and Agnieszka Majos. 2017. "Obesity in Menopause - Our Negligence or an Unfortunate Inevitability?" Przeglad Menopauzalny 16(2): 61-65. (09 Oktober 2019)

Kusumanigsih, Dyah. 2019. Perbedaan Krakteristik Keluhan Pada Perempuan Menopause Yang Mengikuti Dan Tidak Mengikuti Posyandu Lansia Di Wilayah Kerja Puskesmas Mojo Surabaya. Surabaya. http://repository.unair.ac.id/id/eprint/86261 (09 September 2019)

Lee Suk, Hyun HJ. 2011. "Association between postmenopausal symptoms and metabolic syndrome in postmenopausal women". Archives of Gynecology and Obstetric. University of Korea

Mallhi, Tauqeer Hussain et al. 2018. "Managing Hot Flushes in Postmenopausal Women: A Review." Journal of the College of Physicians and Surgeons Pakistan 28(6): 460 65. (10 Oktober 2019)

Prastiwi, Evi., Agustina, Wiwik., Fatmawati, Diana. 2018 . Pengaruh Obesitas sentral terhadap status kesehatan karyawan STIKES Maharani Di Kota Malang. Jurnal Ilmiah Kesehatan : Media Husada

RISKESDAS. 2019. "Laporan Hasil Riset Kesehatan Dasar (Riskesdas) Indonesia Tahun 2018." Badan Penelitian dan Pengembangan Kesehatan: $1-627$. https://www.litbang.kemkes.go.id/laporan- 
riset-kesehatan-dasar-riskesdas/.

September 2019)

Ryu KJ, Park HT, Kwon DH, et al. Vasomotor symptoms and metabolic syndrome in Korean postmenopausal women. Menopause 2015; 22: 1239-1245. PubMed PMID: 25899005.

Sayan, S., \& Pekin, T. (2018). Relationship between vasomotor symptoms and metabolic syndrome in postmenopausal women. https://doi.org/10.1177/0300060518790709

(05 Juli 2020)

Sofa, Ira Maya. 2018. "Kejadian Obesitas , Obesitas Sentral , Dan Kelebihan Lemak Viseral Pada Lansia Wanita The Incidence of Obesity, Central Obesity, and Excessive Visceral Fat among Elderly Women." Amerta Nutr: 228-36 (03 Desember 2019)

Tuomikoski, Pauliina, and Hanna SavolainenPeltonen. 2017. "Vasomotor Symptoms and Metabolic Syndrome." Maturitas 97: 61-65. http://dx.doi.org/10.1016/j.maturitas.2016.12.0 10. (10 Oktober 2019)

World Health Organization. 2008. Waist Circumference And Waist-Hip Ratio. Report of a WHO Expert Consultation. Geneva

Wingert, pat, and Barbara Kantrowitz. 2018. The Menopause Book. ketiga. New York: Workman Publishing Co,Inc. (10 Oktober 2019) 